\title{
OPERATIONS DATA APPENDIX ${ }^{1}$
}

\author{
Shipboard Scientific Party ${ }^{2}$
}

\section{INTRODUCTION}

\section{Leg 169 Technical Accomplishments}

Hole $856 \mathrm{H}(500.0 \mathrm{~m}$ total depth [TD]) was the first penetration of an oceanic sulfide mound through the massive sulfides, stockwork mineralization zone, underlying sediment, basalt sills, and an upper pillow basalt section. The first logs were obtained through an oceanic sulfide mound at Hole $856 \mathrm{H}$. Pop-Up Pore Pressure Instruments (PUPPIs) were deployed and recovered at Holes 1036B and 1036C.

\section{Report Depths and Times}

Depth measurements are in meters. Unless otherwise noted, depths in this report refer to meters below rig floor (mbrf), in which drill pipe measurements (DPM) are referenced to the top of the dual elevator stool on the rig floor. The DPM depths during Leg 169 were 11.1-11.8 $\mathrm{m}$ above sea level (depending on the ship's draft). Meters below seafloor (mbsf) refers to the indicated depth below the seafloor, which is based on recovery or apparent seafloor contact for each hole. Unless otherwise noted, all times in this report refer to ship time. The shipboard clocks were maintained on United States Western Time Zone $=$ Greenwich Mean Time -7 hr. Shipboard times remained the same for the entire leg. Sites were positioned during the leg by using the shipboard differential Global Positioning System (dGPS) to position on GPS coordinates from previous site surveys. All bottom-hole assemblies used consisted of two stands of 5.5-in transition drill pipe. a tapered drill collar, and several 8.25-in drill collars.

\section{PORT CALL IN VICTORIA, B.C.}

Leg 169 began with the first line ashore in Victoria, B.C. at the Ogden Point, WestCan Terminal, Pier A at 1515 hr on 21 August. Normal port call activities and unloading and loading had been completed on 16 and 17 August during the Leg 169S port call, so the Leg 169 port call was primarily for the purpose of changing scientific parties. The cores from Saanich Inlet Holes 1033B and 1034B were offloaded. The ship's departure was delayed for a few hours while a replacement flew in to replace the Ocean Drilling Program (ODP) curator, who had a medical problem. The last line ashore was at $0045 \mathrm{hr}$ on 22 August, and the ship departed for Hole 858G.

\section{TRANSIT FROM VICTORIA TO SITE 858}

The 218-nmi transit from Victoria to Hole $858 \mathrm{G}$ required $20 \mathrm{hr}$ and $25 \mathrm{~min}$ at an average speed of $10.76 \mathrm{kt}$. The course was changed to clear a large fleet of fishing vessels.

${ }^{1}$ Fouquet, Y., Zierenberg, R.A., Miller, D.J., et al., 1998. Proc. ODP, Init. Repts., 169: College Station, TX (Ocean Drilling Program).

${ }^{2}$ Shipboard Scientific Party is given in the list preceding the Table of Contents.

\section{SITE 858}

\section{Hole $858 G$}

Operations began as we dropped a Datasonics 354M retrievable commandable beacon $(208 \mathrm{~dB})$ at $2115 \mathrm{hr}$ on 22 August on the dGPS coordinates for Hole 858G: latitude $48^{\circ} 27.360^{\prime} \mathrm{N}$, longitude $128^{\circ} 42.531^{\prime} \mathrm{W}$. We then ran a data logger retrieval bottom-hole assembly (BHA). The BHA was positioned over the Hole 858G dGPS coordinates, and we ran the vibration-isolated television (VIT) frame down the drill string. The modified Circulation Obviation Retrofit Kit (CORK) running tool jayed-in after numerous attempts by setting down a 15,000-lb weight and applying left-hand torque. A 10,000-lb test pull confirmed latch-in. The driller noted a 400-lb overpull, and we assumed that the data logger released and was being retrieved at $2 \mathrm{~m} / \mathrm{min}$ on the wireline. When the 400 -m-long thermistor string would have been clear of the CORK, we made numerous unsuccessful attempts to unjay from the CORK. Something appeared to be preventing movement of the running tool. The ship was offset $\sim 5 \mathrm{~m}$ in a circle around the site, and $\sim 15,000 \mathrm{lb}$ of weight was set down with right-hand torque to release the running tool. After unjaying, the ship was moved $20 \mathrm{~m}$ off the hole to retrieve the data logger overshot. Inspection of the television image indicated the overshot tool was empty and did not appear to have engaged the data logger. The running tool was pulled to the rig floor for inspection to determine why engagement and release were so difficult. The bottom end of the funnel on the running tool was bent in two places (from setting down on remotely operated vehicle [ROV] platform ribs?), and we noted some wear in the jay slots, indicating that the running tool may have been tilted slightly relative to the CORK. The funnel was shortened by 3 in, the jay slots were dressed, the skirt lip was beveled in the jay slot, the running tool was painted black to reduce glare from the VIT lights, and the 75-W television light was replaced with a 50-W bulb. We continued by running the modified CORK running tool again, but by this time the seas had increased to 6-7 ft, heave was 1-2 $\mathrm{m}$, the roll was erratic, and the weight indicator was varying by 20,000 $30,000 \mathrm{lb}$. Although winds were only up to $17 \mathrm{kt}$ on location, local seas were in a confused state. The attempt to stab over the CORK was aborted and we tripped the drill string. The beacon was turned off and left in place for the return as soon as weather permitted.

\section{SITE 856}

\section{Hole $856 \mathrm{H}$}

The ship was moved in dynamic positioning (DP) mode to Hole $856 \mathrm{H}$ on 24 August, where a drill-in-casing had been set with $12 \mathrm{~m}$ of $11^{3 / 4}$-in casing during Leg 139 . The hole had been cored to 93.8 mbsf. Operations were terminated on Leg 139 because of unstable hole conditions. Recognizing there was a possibility that several years of oxygenated water flow in the open hole had cemented or stabilized some of the upper hole section, we set out to deepen the existing hole. Our plan was to obtain a temperature profile and fluid sample and attempt to deepen the hole. The water depth was $2434.5 \mathrm{mbrf}$. The hole was relocated and reentered in $45 \mathrm{~min}$. The bit encountered fill at $73.8 \mathrm{~m}$, and the hole was washed $20 \mathrm{~m}$ in soft fill to total depth at $93.8 \mathrm{~m}$ with moderate torque and restriction of rotation on the last

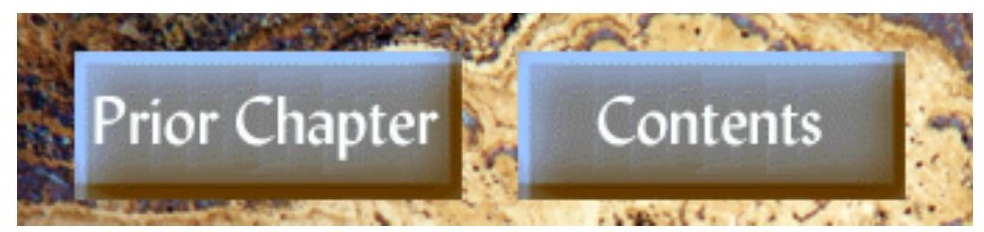


connection. Rotary core barrel (RCB) wash barrel Core $169-856 \mathrm{H}-$ $18 \mathrm{~W}$ was pulled with three pieces of massive sulfide recovered. Coring $406.2 \mathrm{~m}$ required 88.5 operating hr, including two precautionary short trips. The rate of penetration averaged $5.0 \mathrm{~m} / \mathrm{hr}$ in massive sulfides and $38.4 \mathrm{~m} / \mathrm{hr}$ in hydrothermally altered mudstones. Recovery was reduced by brittle mudstone fracturing and jamming in the eightfinger and eight-finger combination core catchers and core liner. Hole conditions while coring during Leg 169 were good with only occasional erratic torque end of each core. Coring parameters were $10,000-25,000 \mathrm{lb}$ weight on bit (WOB) and $50 \mathrm{rpm}$ at 100-200 A torque, circulating $250 \mathrm{gpm}$ at $350 \mathrm{psi}$.

After conditioning the hole for logs, we dropped the core bit on the seafloor with a mechanical bit release to leave the hole clean for future drilling. We reentered the hole with the open-ended drill string that was set at $22.5 \mathrm{mbsf}$ for logging. The main logging tools had relatively low temperature ratings (Triple Combo and Sonic/FMS to $175^{\circ} \mathrm{C}$ and the Geochemical tool to $130^{\circ} \mathrm{C}$ ); therefore, we decided to run a temperature log first to check bottom-hole temperatures and thermal rebound rates. We chose the temperature tool from the $\mathrm{Bu}-$ reau de Recherches Géologiques et Minières (BRGM) in Orleans, France, for the first run because it was rated to $250^{\circ} \mathrm{C}$. The $2.5-\mathrm{m}-$ long BRGM temperature tool weighed only $\sim 50 \mathrm{~kg}$, and the loggers were advised that it was not heavy enough to meet Ocean Drilling Program third-party tool guidelines (227 kg minimum). We added a $1 \frac{1}{2}$-in slotted sinker bar $(30 \mathrm{~kg}$ ) to the line, but the tool weight was still not adequate to permit the winch operator to recognize the weight of the tool given the far greater weight of the winch cable. We ran the logging line to an apparent depth of $471 \mathrm{mbsf}$, but were forced to pull the BRGM tool because of erratic readings. The logging tool had evidently stopped on a shallow ledge or bridge at $\sim 61 \mathrm{mbsf}$ (without the winch operator's knowledge) while the logging line continued to be run into the hole. The new Schlumberger high-temperature logging line was twisted, kinked, and knotted and $300 \mathrm{~m}$ had to be removed. We attempted to clean out the ledges with the open end pipe, and although the pipe could be worked past ledges from 50 to 63 mbsf, we could not work it any deeper and were forced to trip the pipe.

\section{DEPLOYING PUPPIS}

During the last pipe trip mentioned previously, on 29 August, the ship moved in DP mode to Site 1036, and the two PUPPIs were dropped on the locations of planned Holes 1036B and 1036C, respectively. We did this to achieve deployment without using ship time specifically for this purpose. After PUPPI deployment, the ship returned to Hole $856 \mathrm{H}$.

\section{RETURN TO HOLE 856H}

We ran a reentry/logging bit as part of the BHA to reenter Hole $856 \mathrm{H}$, because we assumed the problems we encountered were because of ledges in the borehole. This assumption was based on Leg 139 logs and the behavior of the open-ended pipe on our previous reentry attempt. The hole was reentered in $45 \mathrm{~min}$, but we could not work the bit past an obstruction at $61 \mathrm{mbsf}$, where a ledge was evident on Leg 139 logs. We had to pull the logging bit and noted severe wear on the throat and outside of the bit face, indicating that a hard material had blocked the hole. The hole was unstable and bridging over, so we ran a 97/8-in Smith three-cone drill bit to clean out the hole. The hole required reaming in the intervals from 36.5 to $93.5,126.5$ to 209.5 , 375.5 to 395.5 , and 487.5 to 500.0 mbsf. After a conditioning trip back to $85 \mathrm{mbsf}$, we noted and cleaned out $11 \mathrm{~m}$ of fill from the bottom of the hole. In an effort to stabilize the hole and reduce the potential inflow of hot water, we spotted sepiolite mud $(115 \mathrm{bbl})$ in the hole and dropped the bit in the bottom of the hole. We then pulled the open end of the pipe to 85 mbsf for logging. We ran a Triple Combo logging tool to $495 \mathrm{mbsf}$. Following the Triple Combo logging run, we ran the Gamma-ray/Sonic/Formation MicroScanner (FMS) tool to $491 \mathrm{mbsf}$. The FMS data looked erratic (the internal tool temperature read $86^{\circ} \mathrm{C}$ ), and the tool appeared to be slipping with or without the wireline heave compensator. We pulled the tool and noted that an external temperature tab read $182^{\circ} \mathrm{C}$ (the FMS temperature rating has a maximum of $175^{\circ} \mathrm{C}$ ). The Schlumberger FMS logging tool has an internal temperature sensor that was reading $90^{\circ} \mathrm{C}$. The FMS sonde was damaged by heat, and the transmitter was damaged, which left only one operational FMS tool. We ran the open end of the drill string to $500 \mathrm{mbsf}$ and circulated surface water into the hole for $1 \mathrm{hr}$ (two hole volumes) to cool the hole. We then pulled the end of the pipe back to $85 \mathrm{mbsf}$ and made a second run with the Gamma-ray/FMS (no Sonic) to 385 mbsf. The second FMS run was successful, but the external temperature tab read $176^{\circ} \mathrm{C}$ when the tool was retrieved, so we canceled the geochemical log because the temperature rating of the tool is $130^{\circ} \mathrm{C}$. The pipe cleared the rotary table at $1330 \mathrm{hr}$ on 1 September. The primary beacon was generating erratic signals, so it was recovered. The backup beacon was turned off for the return to Site 1035 .

\section{RETURN TO HOLE 858G}

The ship returned to Hole $858 \mathrm{G}$ in DP mode during the trip to pick up the modified CORK running tool. The environmental conditions were good (seas $2 \mathrm{ft}$, swells $5 \mathrm{ft}$, and heave $0.6 \mathrm{~m}$ ). The hole was reentered in $15 \mathrm{~min}$; however, the running tool rotated freely indicating that it had not jayed-in. After putting 15,000 lb on the running tool, an overpull to $10,000 \mathrm{lb}$ indicated successful latching with the CORK. We ran the data logger overshot on the wireline, and made an unsuccessful attempt to retrieve the data logger by jarring and pumping with $15,000 \mathrm{lb}$ weight down to $10,000 \mathrm{lb}$ tension on the running tool. The running tool appeared to release easily, and the VIT image showed the upper portion of the CORK and possibly the upper mandrel and data logger (without instrument cable) engaged in the running tool body. We pulled the overshot tool and the running tool which, unfortunately, was empty when it got to the rig floor. Wear on the latching slots in the running tool indicated that we had engaged the CORK, but the data logger must have slipped from the overshot tool while pulling the drill string.

We ran the CORK pulling tool again in an attempt to retrieve the bottom latch and seal portion of the CORK. The reentry required 2.25 $\mathrm{hr}$ and was more difficult because the flat skirt on the tool was difficult to position in the small throat on the flat ROV platform. A tapered throat on the ROV platform would aid in reentry. We were able to maneuver the CORK pulling tool down several meters into the throat of the reentry funnel using $15,000 \mathrm{lb}$ of weight and $250 \mathrm{gpm}$ of water circulation at $150 \mathrm{psi}$, but the tool would not latch into the lower CORK body. It appeared on the VIT image that the running tool might be hanging up on the ROV platform. We modified the ROV platform pulling tool to change it from wireline to free fall deployment, and dropped it down the drill string, where it engaged the ROV platform grating with both arms.

We worked the pipe up and down and circulated water while engaging the platform recovery tool, and noted that the CORK recovery tool had moved down another $1.5 \mathrm{~m}$ over the CORK. When we attempted to pull the platform recovery tool, we discovered the CORK recovery tool had latched into place. We increased tension on the CORK for $45 \mathrm{~min}$, and it finally broke free using 100,000 lb of overpull. It took $4.25 \mathrm{hr}$ to recover the lower CORK body and ROV platform and another $5 \mathrm{hr}$ to lay down the tools, including sampling for biological samples and minerals. The ROV platform was only held by one blade on the platform pulling tool and both blades on the other 
arm had been overloaded and bent down. The inside of the lower CORK body was full of 3-in-thick mineralized deposits. The viton seals were brittle and had failed, allowing hydrothermal fluids to circulate past the seals and through the upper CORK body. The nuts were gone (by cathodic corrosion?) from four of eight release rods. All surfaces were coated with a fine black film about $1 \mathrm{~mm}$ thick. The 400-m-long kevlar thermistor string and 2-m-long stainless steel weight bar remained in the hole. No trace of the kevlar was found.

We ran a 9-7/8-in C-7 rotary bit to clean out the hole if required, and the bit was set at 2446 mbrf ( $20 \mathrm{mbsf}$ ) for fluid sampling. The water sampler temperature probe (WSTP) tool was run to $2443 \mathrm{mbrf}$, and a good hydrothermal fluid sample was obtained. However, the $150^{\circ} \mathrm{C}$ limit of the temperature tool was approached, the gradient record was lost, and an O-ring leak shorted out the electronics. Next, we ran the Ultra High Temperature-Multi Sensor Memory-Geophysical Research Corporation (UHT-MSM-GRC or Becker) temperature tool for the first time ever. The tool is $2.6 \mathrm{~m}$ long and has a $5.4-\mathrm{cm}$ diameter. The tool has a temperature rating of $350^{\circ} \mathrm{C}$, and is run on the coring wireline. The Becker tool set down on an obstruction at 2631 mbrf ( $205 \mathrm{mbsf}=64.7 \mathrm{~m}$ above the $113 / 4$-in casing shoe $)$ and read a constant $273^{\circ} \mathrm{C}$ from 205 to 20 mbsf, which indicates flow of high-temperature fluid up the hole. The lithium batteries were $90^{\circ} \mathrm{C}$ when the tool was retrieved and were allowed to cool before extracting the samples. In as much as lithium batteries have a temperature rating of $150^{\circ} \mathrm{C}$ and could explode at $180^{\circ} \mathrm{C}$, a safety procedure was adopted to cool the batteries on future runs.

Our last tool run involved the Los Alamos fluid sampler that was set at $200 \mathrm{mbsf}$ (2526 mbrf). Unfortunately, the viton valve seats melted and the hydrothermal fluid sample mixed with seawater on the wireline trip out. The bit tagged fill at 205 mbsf (same as the Becker tool). To avoid circulating cold seawater into the hole, we attempted unsuccessfully to rotate down without circulation. The hole was cleaned out to $387 \mathrm{mbsf}$ in soft material, but the pipe stuck at 326 mbsf when pulling out of the hole. The driller worked the pipe for 4 hr at up to 200,000 lb overpull, but the rotary was stalled at $800 \mathrm{~A}$ and the hole was packing off ( $500 \mathrm{psi}$ at $50 \mathrm{gpm}$ ). To avoid contaminating the hole for water samples, we had pumped no mud while cleaning out the hole. Given our stuck pipe situation, however, we decided to run a 20 - and 30-bbl tandem sepiolite mud sweep that immediately freed the pipe. There was a second minor stuck pipe incident at 278 mbsf because circulation stopped before the mud cleared the seafloor.

We retrieved a wash barrel (Core 169-858G-18W) that contained loose sulfides, anhydrite, and plastic electrical wrap and insulation from the thermistor string. We never recovered any of the kevlar cable. We used circulation to clean out the reentry cone throat in the CORK setting and seal area and made a short trip to $385 \mathrm{mbsf}$ without tagging fill. Deciding we were ready to attempt setting the new CORK, the rotary bit was pulled after $31 \mathrm{hr}$ in $\sim 273^{\circ} \mathrm{C}$ hydrothermal fluid. The body was blackened, the cones rotated easily, and a few teeth were chipped; however, the bit still appeared usable.

We reentered the hole with a CORK assembly at $2130 \mathrm{hr}$ on 4 September. We set the CORK and ran in a 400-m-long kevlarencased thermistor string (eight sensors) with a 2-m stainless steel sinker bar on bottom. The data logger latched in successfully, but had to be jarred off. The CORK was landed and latched in at 1000 psi and a 10,000-lb pull verified positive seat and seal. The CORK was released at $0745 \mathrm{hr}$ on 5 September. A new solid-deck ROV platform was dropped, and a VIT inspection showed the platform and CORK were in good shape. The beacon was turned off for a later return to the Dead Dog sites. The weather forecast was good for the next few days, so we decided to go to Hole 857D for another CORK replacement job.

\section{HOLE 857D}

We made the 0.6-nmi transit in $1 \mathrm{hr}$ in DP mode while running pipe. We deployed two Datasonics 354M beacons because the first released for unknown reasons. Hole 857D was drilled to $936 \mathrm{mbsf}$ on Leg 139 and has a reentry cone with 113/4-in casing set at $573.8 \mathrm{mbsf}$ (3005.0 mbrf). The water depth is 2431.5 mbrf. The CORK was set with a 300-m-long thermistor and fluid sampler string. This CORK was knocked over on Leg 146 by a collision with the running tool in high heave conditions during a recovery attempt. The Alvin submersible installed an overshot on the data logger in a subsequent unsuccessful fishing attempt, but the rope broke. Our objective was to retrieve the damaged CORK and 300-m thermistor string, deepen the hole, and reCORK the hole.

We were able to stab the running tool over the damaged CORK data logger by $1945 \mathrm{hr}$ on 5 September. Once again, however, we experienced difficulty latching onto the CORK, and suspected interference with the ROV platform (the platform was damaged from a heavy blow on Leg 146). We decided to try to remove the ROV platform and ran the platform pulling tool which engaged both arms, and the platform came free with $40,000 \mathrm{lb}$ of pull. No other parts of the CORK assembly could be seen on the VIT image, so we dropped the platform on the seafloor $70 \mathrm{~m}$ southwest of Hole 857D to save the time required for a pipe trip.

When returning to the CORK, we noted that the data logger was missing and something was protruding from the CORK pulling tool. We pulled the pipe that contained the upper CORK body (above the sealing bulkhead and six release rods). The thermistor string and sinker bar were not recovered. The CORK body had few deposits and appeared to have had an effective seal. A long length of rope dumped by the Alvin was wrapped around the CORK body. The remaining part of the CORK still in the reentry cone was a 51/4-in diameter data logger seal sleeve and mandrel extending 26 in above a sealing bulkhead, with a latch ring, seal, and lower CORK body below. The seal sleeve was 10 in below the throat. We ran an 8-7/8-in overshot with a 5-3/8-in basket grapple that was slightly larger than desirable, but it was the closest catch size available for an outside catch of the data logger sleeve. We shortened the cut lip guide and welded a 22 -in funnel above the overshot to act as a centering guide in the 24-in-wide reentry cone throat. Since the weather was rapidly deteriorating with 18- to 27-kt winds and rain, we also ran a bumper sub.

Even after several attempts, we could not stab the overshot tool over the remainder of the CORK, so we pulled the assembly. Marks on the overshot tool indicated that the centering guide was ineffective because it was too far above the cut lip guide. Since the centering guide could not be welded to the overshot body, it was welded on a short 9-5/8-in stem, so the funnel could be positioned just above the cut lip guide. We ran the overshot assembly again, this time without the bumper sub. The overshot engaged and the CORK pulled free with $30,000 \mathrm{lb}$. The ship was offset $70 \mathrm{~m}$ southwest, and we pulled the overshot tool. Once on deck, however, there was not even a partial CORK assembly in the recovery tool. However, the wear on the grapple indicated it had likely latched successfully, so we assumed that the CORK was dropped on the seafloor some distance to the southwest of the hole (direction of drift).

We configured a wireline spear to fish the thermistor string, sinker bar, and the bottom of the data logger (if they remained in the hole). The spear had a hole in the nose, and the temperature and fluid samplers were checked to ensure adequate internal clearance. We ran the wireline spear to the seafloor, and used the VIT to search the seafloor for the dropped CORK assembly without success. The spear reentered Hole $857 \mathrm{D}$ and tagged an obstruction at $20.8 \mathrm{mbsf}$. Rotating the spear successfully secured the cable, and we pulled it to the ship. To prevent fouling the thrusters with the cable, we turned the ship broadside to the current, shut down the center thrusters, and posted observers to look for floating cable. We recovered a significant portion of 
the thermistor string (but not the sinker bar), consisting of $>200 \mathrm{~m}$ of braided kevlar cable and tygon water sample tube. We clamped off the water sample tube in sections to preserve fluid samples. The braided kevlar jacket had deteriorated progressively with depth below 200 mbsf. The bottom of the sample tube was colored and plugged with clay, indicating possible contact with sediments during recovery. Inspection of the fishing tool indicated we had left four $1 / 2$ by 3 -in-long spear prongs in the hole in addition to the 270 -lb thermistor sinker bar. The temperature and fluid sampler tools were being serviced and repaired, so we decided to go to Site 1035 to continue operations there. Planning for a return to this location, we turned the beacon off, and the bit cleared the rotary table at $2100 \mathrm{hr}$ on $7 \mathrm{Sep}-$ tember.

\section{SITE 1035 Hole 1035A}

We moved in DP mode to $48^{\circ} 26.020^{\prime} \mathrm{N}, 128^{\circ} 40.920^{\prime} \mathrm{W}, \sim 75 \mathrm{~m}$ west of Hole $856 \mathrm{H}$. Hole 1035A would be the first of our planned east to west transect across the Bent Hill Massive Sulfide (BHMS) deposit. We were unable to reactivate the beacon from Hole $856 \mathrm{H}$, so we dropped a new beacon. We ran an advanced piston corer (APC)/ extended core barrel (XCB)/motor-driven core barrel (MDCB) BHA. We initiated Hole 1035A at $0600 \mathrm{hr}$ on 8 September. The seafloor was at 2456.4 mbrf. We recovered APC Cores 169-1035A-1H through $6 \mathrm{H}$ from 0 to $55.0 \mathrm{~m}$ with $100 \%$ recovery. The last two cores were partial strokes with $20,000-40,000 \mathrm{lb}$ overpull, and the liner was shattered on the last core, prompting a change to the XCB system. XCB Cores 169-1035A-7X through 19X were taken from 55.0 to $170.8 \mathrm{~m}$ with $55.6 \%$ recovery. Five of 13 cores jammed in the core catcher, and the XCB hard formation shoe was destroyed on the last core. We decided to return to Hole 857D to finish the cleanout and CORK installation. The bit cleared the rotary table at $2100 \mathrm{hr}$ on 9 September. One beacon was recovered and the second was turned off.

\section{Return to Hole 857D}

The ship was moved in DP mode back to Hole 857D while tripping pipe. The beacon was turned back on. Hole 857D was reentered with a rotary bit at $2200 \mathrm{hr}$ on 9 September, and the bit was run in to $22 \mathrm{~m}$. Silt stirred up in the water that was being sucked down the hole, confirming that the hole was still taking water. A sinker bar was run in to $642 \mathrm{~m}$, and an external temperature tab indicated the maximum temperature was $<108^{\circ} \mathrm{C}$. Drill pipe was run in to $377 \mathrm{~m}$, where an obstruction was noted. The hole was washed and reamed from 359 to $446 \mathrm{~m}$ against generally light resistance using $5000 \mathrm{lb}$ WOB. The pipe was run in to $621 \mathrm{~m}$, and a WSTP water sample was taken. The temperature was $2^{\circ} \mathrm{C}$, and the sample proved to be seawater, which confirmed a strong downflow to that depth. The hole was washed and reamed against light resistance from 611 to $929 \mathrm{~m}$ (3360 mbrf or $8 \mathrm{~m}$ above TD).

Left in Hole $857 \mathrm{D}$ are one 21/2-in by 2-m-long, 270-lb thermistor sinker bar and four each $1 / 2$-in by 3 -in-long wireline spear prongs. We decided not to deepen the hole because of time constraints and a questionable long term weather forecast. Hole conditions appeared to be stable with occasional light resistance and minor ledges noted. The bit cleared the rotary at $2000 \mathrm{hr}$ on 10 September and had anhydrite on the teeth and spiral stabilizer blades. Hole 857D was reentered with a CORK assembly at $0200 \mathrm{hr}$ on 11 September. A $2^{1 / 2-i n}$ by $2-$ m-long, 270-lb sinker bar, $898 \mathrm{~m}$ of 5/8-in braided kevlar thermistor string with nine thermistors, and a data logger were run on coring wireline (CWL), latched into the CORK, and test pulled to $15,000 \mathrm{lb}$. The ROV platform was dropped at $0845 \mathrm{hr}$. The installation was checked with the VIT, and the CORK was released at $1000 \mathrm{hr}$. The running tool cleared the rotary at $1445 \mathrm{hr}$ on 11 September.

\section{Hole 1035B (Proposed Site BH-7)}

The ship was moved in DP mode to Hole 1035B, 51 m south of the Bent Hill massive sulfide deposit. The same APC/XCB/MDCB BHA was run. Hole 1035B was spudded at $2130 \mathrm{hr}$ on 11 September. Core $169-1035 \mathrm{~B}-1 \mathrm{H}$ was a partial stroke in a hard layer near the seafloor, and the core barrel could not be pulled. The television revealed that the core barrel was bent at $\sim 90^{\circ}$. The pipe was pulled, and a small sample of mud was taken for paleontological reference from the bent core barrel and archived as Core 169-1035B-1H. The bit cleared the rotary at $0530 \mathrm{hr}$ on 12 September.

\section{Hole 1035C (Proposed Site BH-7)}

The ship was not moved because hard massive sulfides at the seafloor were assumed to be the cause of the APC refusal on Hole 1035B. The VIT was run because of the bent core barrel and an unclear seafloor indication on the precision depth recorder (2465.4$2469.4 \mathrm{mbrf}$ ), and the seafloor was found at $2459.0 \mathrm{mbrf}$. Hole $1035 \mathrm{C}$ was spudded at $1215 \mathrm{hr}$ on 12 September. The XCB coring system was used for spudding because of the hard surface. XCB Cores $169-1035 \mathrm{C}-1 \mathrm{X}$ through $5 \mathrm{X}$ were taken from 0 to $44.0 \mathrm{~m}$ (2503.0 mbrf) with $4.8 \%$ recovery. Core $169-1035 \mathrm{C}-4 \mathrm{X}$ had some torque, and a mud sweep was circulated. On Core 169-1035C-5X, there was $7 \mathrm{~m}$ of fill on the connection, and the torque increased despite circulating another mud sweep. The pipe was pulled because the hole was unstable and caving in. The bit cleared the seafloor at 2050 $\mathrm{hr}$ on 12 September. A strobe light was noted on the surface $\sim 1 \mathrm{nmi}$ northwest of the ship. As soon as the bit cleared the seafloor, the ship gave chase on the assumption that one or both of the PUPPIs had released prematurely. Beacon 774 was recovered and had released for unknown reasons from near Hole 858G on the Dead Dog mound.

\section{Hole 1035D (Proposed Site BH-2)}

The ship was moved in DP mode to Hole 1035D on the east side of the BHMS deposit $\sim 73$ m east of Hole $856 \mathrm{H}$. The water depth was 2459.8 mbrf. Hole 1035D was spudded at $0100 \mathrm{hr}$ on 13 September. APC Cores 169-1035D-1H through 5H were taken from 0 to $40.6 \mathrm{~m}$ ( 2500.4 mbrf) with $110.5 \%$ recovery. Core $169-1035 \mathrm{D}-5 \mathrm{H}$ was a partial stroke that penetrated no more than $7.0 \mathrm{~m}$ (the bit hit a hard layer) and had at least $2 \mathrm{~m}$ of suck-in for a 9.91-m apparent recovery. XCB Cores 169-1035D-6X and 7X were taken from 40.6 to $57.7 \mathrm{~m}$ with $2.9 \%$ recovery. Broken sulfides, anhydrite, and pyrite nodules jammed in the core catchers. Massive sulfides with anhydrite cementation were cored successfully at the Trans-Atlantic Geotraverse, using the MDCB system, and anhydrite cementation was increasing; therefore, the MDCB system was run in an attempt to improve recovery. The hole was drilled with an XCB shoe and center bit from 57.7 to $59.3 \mathrm{~m}$, and a mud sweep was circulated to clean the hole. The MDCB was run with standard thruster and bit nozzles, $5000 \mathrm{lb}$ WOB, and no DP rotation, circulating $38 \mathrm{spm}$ (190 gpm) at $1225-1200 \mathrm{psi}$. Core $169-1035 \mathrm{D}-8 \mathrm{~N}$ was taken from 59.3 to $60.8 \mathrm{~m}$ (1.5 $\mathrm{m}$ stroke per paint marks on the core barrel) in $15 \mathrm{~min}$ with $0.09 \mathrm{~m}(6.0 \%)$ recovery. XCB coring was resumed with Cores 169-1035D-9X through $24 X$ from 60.8 to $178.5 \mathrm{~m}$ (2638.3 mbrf) with 5.0\% recovery. Recovery was poor because 13 of $18 \mathrm{XCB}$ cores jammed in the XCB shoe throat and core catcher. Operations were terminated when the objective of the hard layer at $\sim 170 \mathrm{mbsf}$ was reached.

\section{Hole 1035E (Prospectus Site BH7)}

The ship was moved in DP mode to the next location at Hole $1035 \mathrm{E}$ (site BH) $\sim 100 \mathrm{~m}$ south of Hole $856 \mathrm{H}$. The water depth was 2465.0 mbrf. APC Cores 169-1035E-1H through $5 \mathrm{H}$ were taken from 0 to $45.5 \mathrm{~m}$ (2510.5 mbrf) with $104.8 \%$ recovery. Core $169-1035 \mathrm{E}-$ 
$5 \mathrm{H}$ was a partial stroke that bounced back and wrapped the CWL around the sinker bars. The CWL then parted at 12,000 lb overpull when attempting to pull it, and the BHA was pulled.

\section{SITE 1036}

\section{Hole 1036A (Prospectus Site DD-1)}

The ship was moved in DP mode to Site 1036. A VIT survey was run for $2.25 \mathrm{hr}$ to locate the top of the Dead Dog mound and confirm that the site was free of clams. The water depth was 2419.0 mbrf. Hole 1036A was spudded at $2115 \mathrm{hr}$ on 15 September. APC Cores 169-1036A-1H through $4 \mathrm{H}$ were taken from 0 to $33.0 \mathrm{~m}$ (2452.0 mbrf) with $103.8 \%$ recovery. Core $169-1036 \mathrm{~A}-4 \mathrm{H}$ was a partial stroke, and the core liner had to be pumped out of the core barrel in pieces. XCB Cores 169-1036A-5X and 6X were taken from 33.0 to $38.5 \mathrm{~m}$ ( $2457.5 \mathrm{mbrf})$ with $10.0 \%$ recovery. The XCB shoe was destroyed in $45 \mathrm{~min}$ on Core 169-1036A-6X; therefore, XCB coring was terminated. The bit cleared the seafloor at $0730 \mathrm{hr}$ on 16 September.

\section{Hole 1036B (Prospectus Site DD-2)}

The ship was moved in DP mode to Hole 1036B. A VIT survey was run for $1.75 \mathrm{hr}$ to locate the edge of the Dead Dog mound and confirm that the site was free of clams. The seafloor was tagged at 2426.0 mbrf. Hole 1036B was spudded at $0945 \mathrm{hr}$. APC Cores 169$1036 \mathrm{~B}-1 \mathrm{H}$ through $3 \mathrm{H}$ were taken from 0 to $27.7 \mathrm{~m}$ with $102.1 \%$ recovery. XCB Cores 169-1036B-4X through $6 \mathrm{X}$ were taken from 27.7 to $52.3 \mathrm{~m}$ (2479.1 mbrf) with $75.0 \%$ recovery. The hole was terminated at the target depth. The bit cleared the seafloor at $1830 \mathrm{hr}$ on 16 September.

\section{Hole 1036C (Prospectus Site DD-3)}

The ship was moved in DP mode to Hole 1036C off the edge of Dead Dog mound. Hole 1036C was spudded at $2045 \mathrm{hr}$ on 16 September. The seafloor was estimated at $2425.1 \mathrm{mbrf}$. APC Cores 169$1036 \mathrm{C}-1 \mathrm{H}$ through $4 \mathrm{H}$ were taken from 0 to $34.9 \mathrm{~m}$ with $101.2 \%$ recovery. XCB Cores 169-1036C-5X and 6X were taken from 34.9 to $54.2 \mathrm{~m}$ (2479.3 mbrf) with $60.0 \%$ recovery. The XCB shoe was destroyed, and the hole was terminated at the target depth. The bit cleared the rotary table at $1000 \mathrm{hr}$ on 17 September.

\section{RECOVERING PUPPIS}

The two PUPPIs that were deployed at Dead Dog mound on 29 August were recalled and recovered.

\section{Hole 1035F (Prospectus Site BH-7)}

The ship was moved in DP mode back to Hole 1035B and offset $10 \mathrm{~m}$ south to use rotary coring to recover the deeper sections. The hole was at the base of the Bent Hill massive sulfide mound and 40 $\mathrm{m}$ south of Hole $856 \mathrm{H}$. The same RCB BHA was run with a mechanical bit release in case the pipe became stuck at the bit. The seafloor was assumed to be at $2459.0 \mathrm{mbrf}$. Hole $1035 \mathrm{~F}$ was spudded at 1500 hr on 17 September. RCB Cores 169-1035F-1R through 23R were taken from 0 to $224.8 \mathrm{~m}$ (2683.8 mbrf) with $10.0 \%$ recovery. The upper hole was unstable, and two sepiolite mud sweeps were required to stabilize the hole. Torque and hole fill were controlled with sepiolite mud sweeps every other core. Five of 23 cores were jammed in the bit throat or core catcher. The plan was to return to Hole $1035 \mathrm{~F}$ for logs after completing other work; therefore, a Free-Fall Funnel (FFF) was deployed. The FFF position was concealed by heavy flow coming out of the hole; however, the FFF appeared to be in position based on sonar returns. The bit cleared the seafloor at $1000 \mathrm{hr}$.

\section{Hole 1035G (Prospectus Site BH-3)}

The ship was moved in DP mode back to Hole 1035A and offset $10 \mathrm{~m}$ east (near the base of the mound) to recover the deeper sections. The hole was $65 \mathrm{~m}$ west of Hole $856 \mathrm{H}$. The seafloor was tagged at 2456.0 mbrf while the VIT was down. Hole $1035 \mathrm{G}$ was spudded at $1245 \mathrm{hr}$ on 19 September. The hole was washed from 0 to $44.4 \mathrm{~m}$ with a center bit through the silty clay interval, and wash barrel Core 169$1035 \mathrm{G}-1 \mathrm{~W}$ had no recovery. RCB Cores $169-1035 \mathrm{G}-2 \mathrm{R}$ through 5R were taken from 44.4 to $83.3 \mathrm{~m}$. The hole was washed from 83.3 to $140.9 \mathrm{~m}$ in silty claystone, and wash barrel Core $169-1035 \mathrm{G}-6 \mathrm{~W}$ had $4.5 \mathrm{~m}$ recovery. RCB Cores $169-1035 \mathrm{G}-7 \mathrm{R}$ through $13 \mathrm{R}$ were taken from 140.9 to $208.5 \mathrm{~m}$ (2664.5 mbrf). Coring was terminated at the target depth. The VIT was run to the seafloor, and a \pm 15 -in hole was observed with a small cuttings mound, no crater, and no visible flow in or out.

\section{Return to Hole 1035F}

The ship was moved in DP mode back to Hole $1035 \mathrm{~F}$ with the VIT down. A strong flow was observed coming out of the FFF throat and billowing upward to $>40 \mathrm{~m}$ above seafloor with abundant suspended debris.

\section{Hole 1035H (Proposed Site BH-8)}

The ship was moved in DP mode to the mound $200 \mathrm{~m}$ south of the BHMS deposit (now called the ODP Mound). The mound was surveyed for a good core site on the upper plateau. Hole $1035 \mathrm{H}$ was spudded at $2030 \mathrm{hr}$ on 20 September on a reasonably flat bench, adjacent to an inactive toppled chimney and $8 \mathrm{~m}$ from the top of the mound. The seafloor was tagged at 2455 mbrf. RCB Cores 169$1035 \mathrm{H}-1 \mathrm{R}$ through $16 \mathrm{R}$ were taken from 0 to $142.3 \mathrm{~m}$ (2597.3 mbrf) with $12.5 \%$ recovery. The standard butyrate (tenite) core liners are rated to $150^{\circ} \mathrm{C}$ service. In Core $169-1035 \mathrm{H}-11 \mathrm{R}$, the butyrate liner melted completely (into a white lump around the core) during a 20min shutdown when the overshot sheared. The butyrate core liners on Cores $169-1035 \mathrm{H}-12 \mathrm{R}$ through $14 \mathrm{R}$ were partially melted.The quickrelease polypak seal at the top of the RCB inner barrel was melted on some runs.

After Core $169-1035 \mathrm{H}-16 \mathrm{R}$ at $142.3 \mathrm{~m}$, the pipe was pulled up to $74.3 \mathrm{~m}$, and the Los Alamos water sampler was run. The sampler timer slid back in the case and failed to go off. A temperature tab on the sampler turned black out to $399^{\circ} \mathrm{C}$. The VIT was run to the seafloor, and a strong flow was observed coming from the hole. RCB Cores $169-1035 \mathrm{H}-17 \mathrm{R}$ through $27 \mathrm{R}$ were taken from 142.3 to 247.9 $\mathrm{m}$ with $11.1 \%$ recovery. Coring was terminated due to time constraints. The Ultem core liners were used well above the design temperature of $200^{\circ} \mathrm{C}$ on Cores $169-1035 \mathrm{H}-15 \mathrm{R}$ through $27 \mathrm{R}$ by maintaining circulation at $175 \mathrm{gpm}$. The liners are extrusion fabricated at $330^{\circ}-357^{\circ} \mathrm{C}$. In Core $169-1035 \mathrm{H}-26 \mathrm{R}$, an Ultem liner melted (like shrink wrap) around the core and sucked into a $\mathrm{V}$ shape above the core. The core was cold when recovered.

In Core 169-1035H-26R, the torque increased from 150 to $200 \mathrm{~A}$ and pressure increased from 400 to $550 \mathrm{psi}$. The pipe was pulled to $74.5 \mathrm{~m}$, and a perforated and blanked off core catcher sub was run with various temperature sensitive tabs and materials (lead, tin, and engineering materials such as O-rings and seals). The temperature tabs indicated a $316^{\circ} \mathrm{C}$ temperature; however, water may have invaded the tab. The butyrate core liner samples were melted and black, the $200^{\circ} \mathrm{C}$ Ultem liner sample was melted, the APC seal ring was dissolved, but the viton and 70 and 90 durometer O-rings were not noticeably affected. 
The Los Alamos water sampler was run to $74.5 \mathrm{~m}$, but failed to get a sample when the O-rings and valve seat failed. The VIT was run to check the well bore, and sample nets were attached to the VIT frame to trap material being expelled from the hole. There was a heavy and relatively clear flow out of the hole with small flakes being blown up to $22 \mathrm{~m}$ above the hole. The VIT sample net was run to $6 \mathrm{~m}$ above the seafloor. The bit cleared the rotary at $0530 \mathrm{hr}$ on $23 \mathrm{Sep}-$ tember.

The drill pipe that had been below the seafloor and the BHA were coated with 1/16 in of anhydrite and clay. All the connections were broken, checked, and redoped as a precaution. The dope had been dried out, and the threads were dry. The bottom two drill collars had to be broken out with rig tongs; however, there was no obvious thread damage. The mechanical drill bit release was jammed with anhydrite and had to be junked. The bit had extensive tooth loss in the heel rows, some broken and chipped teeth in the intermediate rows, four loose cones with failed seals, and minor stabilizer gage wear. The bit cored $681.2 \mathrm{~m}$ in massive sulfides in 38.4 rotating hours, and logged at least $116 \mathrm{hr}$ in hot holes. The beacon was recovered.

\section{Medivac}

Vancouver Island Helicopters chopper arrived at $1130 \mathrm{hr}$ on 22 September to medivac an Overseas Drilling Limited employee suffering from internal bleeding. The chopper took $75 \mathrm{gal}$ of helifuel and departed at $1200 \mathrm{hr}$ for Victoria General Hospital.

\section{TRANSIT TO ESCANABA TROUGH}

The 447-nmi transit to Escanaba Trough required $40.75 \mathrm{hr}$ at an average speed of $10.6 \mathrm{kt}$. The ship was slowed to $6 \mathrm{kt}$, the new sixchannel seismic streamer was deployed to check the signal, and a 6nmi survey was completed in $1.75 \mathrm{hr}$. A Datasonics 354M $211 \mathrm{~dB}$ beacon was dropped at $2300 \mathrm{hr}$ on 24 September on prospectus site ET-7 at $40^{\circ} 57.30^{\prime} \mathrm{N}, 127^{\circ} 30.90^{\prime} \mathrm{W}$. The standard APC/XCB BHA was run.

\section{SITE 1037 (PROPOSED SITE ET-7) Hole 1037A}

Hole 1037A was spudded at $0800 \mathrm{hr}$ on 25 September. The seafloor was estimated at $3314.0 \mathrm{mbrf}$ based on recovery. APC Core 169-1037A-1H was taken from 0 to $9.5 \mathrm{~m}$ (3323.5 mbrf). The recovery was a full core liner $(9.79 \mathrm{~m})$ for $103.1 \%$ recovery; therefore, the seafloor core and measurement were questionable, and the hole was spudded again.

\section{Hole 1037B}

Hole 1037B was spudded at $0840 \mathrm{hr}$ on 25 September. The seafloor was estimated at $3311.9 \mathrm{mbrf}$ based on recovery. APC Cores $169-1037 \mathrm{~B}-1 \mathrm{H}$ through $19 \mathrm{H}$ were taken from 0 to $177.6 \mathrm{mbsf}$ (3489.5 mbrf) with $99.4 \%$ recovery. No orientation was done, but Adara temperature measurements were taken on Cores 169-1037B$3 \mathrm{H}, 5 \mathrm{H}, 7 \mathrm{H}$, and $9 \mathrm{H}$. A WSTP temperature run was canceled because the formation became too hard. Twelve of the last 13 cores were partial strokes. XCB Cores 169-1037B-20X through 55X were taken from 177.6 to $501.2 \mathrm{mbsf}$ (to $3813.1 \mathrm{mbrf}$ ) with $73.1 \%$ recovery. Core 169-1037B-53X was pulled after coring $5.5 \mathrm{~m}$ in $75 \mathrm{~min}$ and wearing out a soft formation XCB shoe. Core 169-1037B-54X reached $4.1 \mathrm{~m}$ in $105 \mathrm{~min}$, and the shoe was jammed. Core 1691037B-55X was pulled after coring $1.5 \mathrm{~m}$ in $50 \mathrm{~min}$, and the hard formation shoe was completely destroyed and grooved in a manner that could indicate a loose bit cone. In addition, the torque was erratic and recovery dropped from near $100 \%$ to $22.5 \%$ in the last three cores; therefore, the bit was pulled because the rock was too hard for the $\mathrm{XCB}$ shoes, and there was a reasonable chance that a cone was loose and could be lost in the hole.

An FFF was dropped and checked with the VIT, showing the FFF top at the seafloor. The APC/XCB bit was worn but in good shape. An RCB BHA with a mechanical bit release (for drilling the sediment section) was run. The hole was reentered at $0545 \mathrm{hr}$ on 30 September, and the bit was washed to bottom with $7 \mathrm{~m}$ of soft fill. RCB Cores 169-1037B-56R through 62R were taken from 501.2 to $546.0 \mathrm{mbsf}$ ( 3857.9 mbrf) with $27.2 \%$ recovery. Basalt was encountered in Core 169-1037B-57R (top at $507.8 \mathrm{~m}$ ), and the overall rate of penetration on the last four cores in solid basalt was $1.5 \mathrm{~m} / \mathrm{hr}$. The last four cores were partial cores that jammed in the liner support sleeve or liner with $43 \%$ recovery. Overall recovery for Hole 1037B was $77.9 \%$. The hole was conditioned for logging with a short trip. The bit was pulled to $247 \mathrm{~m}$ when heavy flow back and an apparent loss of $20,000 \mathrm{lb}$ string weight was noted.

Suspecting a BHA loss, a core barrel was run, but the bit was tagged twice at the correct depth. The circulating pressure indicated the core barrel was not seating, but the string weight with the top drive looked correct; therefore, we assumed that a piece of core had fallen out of the core barrel and opened the float valve. The apparent loss of weight may have been a reduction in drag in the enlarged hole and 10 stands of drill pipe that had been pulled. The bit was run back to bottom, $30 \mathrm{~m}$ of fill was washed and reamed out to bottom, and the bit was dropped. The pump pressure indicated the hole was packing off, so the bit was pulled up one stand to close the sleeve and circulate sepiolite mud.

\section{SITE 1038 (PROPOSED SITE ET1-4) Hole 1038A}

The ship was moved in DP mode $3.1 \mathrm{nmi}$ in $4.5 \mathrm{hr}$ at $0.7 \mathrm{kt}$ to Site 1038 at dGPS coordinates $41^{\circ} 00.012^{\prime} \mathrm{N}, 127^{\circ} 29.633^{\prime} \mathrm{W}$. A Datasonics beacon was dropped at $1556 \mathrm{hr}$ on 2 October. Operations were shut down for $1 \mathrm{hr}$ to reinstall and test the DCS sensor electronic equipment. The VIT was run, and a survey was conducted over Site 1038 for $0.75 \mathrm{hr}$. Marker 6X (deployed by submersible) was located, and Hole $1038 \mathrm{~A}\left(41^{\circ} 00.0163^{\prime} \mathrm{N}, 127^{\circ} 29.6851^{\prime} \mathrm{W}\right)$ was spudded at $0130 \mathrm{hr}$ on 3 October in sulfides. The seafloor was tagged at 3348.0 mbrf. The VIT was pulled, and RCB Cores 169-1038A-1R through $12 \mathrm{R}$ were taken from 0 to $114.5 \mathrm{mbsf}$ ( $3348.0 \mathrm{mbrf}$ ) with $2.3 \%$ recovery. Core 169-1038A-1R encountered massive sulfides, but recovery was very poor in the remaining cores. The VIT was run to check the hole and confirmed that there was no flow from Hole 1038A. The hole at the seafloor was ruggose and $\sim 18$ in wide. The bit cleared the seafloor at $2030 \mathrm{hr}$ on 3 October.

\section{Hole 1038B}

The ship was moved in DP mode 300 m west of Hole 1038A, and the bottom was checked with the VIT. Hole $1038 \mathrm{~B}\left(41^{\circ} 00.0247^{\prime} \mathrm{N}\right.$, $127^{\circ} 29.8707^{\prime} \mathrm{W}$ ) was spudded at $2240 \mathrm{hr}$ on 3 October. The seafloor was tagged at 3266.0 mbrf. RCB Cores 169-1038B-1R through 13R were taken from 0 to $120.5 \mathrm{mbsf}$ (3386.5 mbrf) with $11.5 \%$ recovery. The bit cleared the seafloor at $1700 \mathrm{hr}$ on 4 October. The VIT was not run until after pulling out of the hole because there were three crossing swells from remote storms, which caused rolls to $4 \mathrm{~m}$ and heave to $2.75 \mathrm{~m}$, and the ship could not be rotated because the current was shifting from 0 to $4 \mathrm{kt}$ and abruptly changing direction by more than $90^{\circ}$. 


\section{Hole 1038C}

The ship was moved in DP mode 76 m east and 259 m north of Hole 1038A. A site was selected on top of the mound on the north edge with the VIT survey. Hole $1038 \mathrm{C}\left(41^{\circ} 00.1816^{\prime} \mathrm{N}, 127^{\circ} 29.6037^{\prime} \mathrm{W}\right)$ was spudded at $2200 \mathrm{hr}$ on 4 October. The seafloor was tagged at 3239.0 mbrf. RCB Cores 169-1038C-1R through $4 \mathrm{R}$ were taken from 0 to 41.8 mbsf (3280.8 mbrf) with $7.6 \%$ recovery. The bit cleared the seafloor at $0515 \mathrm{hr}$ on 5 October.

\section{Hole 1038D}

The ship was moved in DP mode $12 \mathrm{~m}$ west and $64 \mathrm{~m}$ south of Hole 1038A. A site was selected with the VIT beside a pile of what appeared to be sulfide chimney fragments and boulders. The seafloor was tagged at $3237.0 \mathrm{mbrf}$, and Hole $1038 \mathrm{D}\left(41^{\circ} 00.1441^{\prime} \mathrm{N}\right.$, $127^{\circ} 29.6146^{\prime} \mathrm{W}$ ) was spudded at $0745 \mathrm{hr}$ on 5 October. RCB Cores 169-1038D-1R through 4R were taken from 0 to 43.8 mbsf (3280.8 mbrf) with $7.4 \%$ recovery. The bit cleared the seafloor at $1540 \mathrm{hr}$ on 5 October.

\section{Hole 1038E}

The ship was moved $300 \mathrm{~m}$ south to Hole 1035A, which still had no flow coming from it. The ship was moved $\sim 35 \mathrm{~m}$ east and $31 \mathrm{~m}$ north of Hole 1038A. The seafloor was tagged at $3221.0 \mathrm{mbrf}$, and Hole $1038 \mathrm{E}\left(41^{\circ} 00.0012^{\prime} \mathrm{N}, 127^{\circ} 29.6463^{\prime} \mathrm{W}\right)$ was spudded at 1845 $\mathrm{hr}$ on 5 October. RCB Cores 169-1038E-1R through 4R were taken from 0 to 40.6 mbsf (3261.6 mbrf) with $5.9 \%$ recovery. The bit cleared the seafloor at $0015 \mathrm{hr}$ on 6 October.

\section{Hole 1038F}

The ship was moved $435 \mathrm{~m}$ south and $525 \mathrm{~m}$ east of Hole 1035A to the edge of a sulfide mound. The seafloor was tagged at 3252.0 mbrf, and Hole $1038 \mathrm{~F}\left(40^{\circ} 59.7304^{\prime} \mathrm{N}, 127^{\circ} 29.2877^{\prime} \mathrm{W}\right)$ was spudded at $0615 \mathrm{hr}$ on 6 October. RCB Cores $169-1038 \mathrm{~F}-1 \mathrm{R}$ through $4 \mathrm{R}$ were taken from 0 to $38.4 \mathrm{mbsf}$ ( $3290.4 \mathrm{mbrf}$ ) with $17.2 \%$ recovery. The RCB BHA was pulled, and the bit cleared the rotary at $1745 \mathrm{hr}$ on 6 October.

\section{Hole 1038G}

We made a pipe trip, and the standard APC/XCB BHA was run to obtain sediment cores near the sulfide mound outcrops on the east side of Bent Hill. The plan was to move the ship $5 \mathrm{~m}$ west of Hole $1038 \mathrm{~F}$ to a 3 - to 4 -m-deep and 20-m-wide depression in the sulfide deposit. Clams in the depression indicated diffuse flow, and the seafloor was tagged at $3251.0 \mathrm{mbrf}$, and Hole $1038 \mathrm{G}\left(40^{\circ} 59.7255^{\prime} \mathrm{N}\right.$, $127^{\circ} 29.2865^{\prime} \mathrm{W}$ ) was spudded at $0245 \mathrm{hr}$ on 6 October. XCB Cores $169-1038 \mathrm{G}-1 \mathrm{X}$ and $2 \mathrm{X}$ were taken from 0 to $22.0 \mathrm{mbsf}$ with no recovery. The bit penetrated through a firm upper surface on Core 169$1038 \mathrm{G}-1 \mathrm{X}$ into soft sediments; therefore, APC coring was initiated. APC Cores 169-1038G-3H through 5H were taken from 22.0 to 50.5 mbsf. Cores 169-1038G-3H and 4H were noticeably warmer and very gassy, and the core liners were blackened by heat. On Core 169$1038 \mathrm{G}-5 \mathrm{H}$, the liner was softened and pushed back up into the liner by the core, which jammed the liner and doubled the thickness of the liner tube (like a tubing upset). XCB Cores 169-1038G-6X through $16 \mathrm{X}$ were taken from 50.5 to $147.0 \mathrm{mbsf}$ (3398.0 mbrf). Basalt was encountered on Cores 169-1038G-15X and 16X. Coring was terminated when the XCB shoe was destroyed on Core 169-1038G-16X.

\section{Hole 1038H}

The ship was moved in DP mode back to Hole 1038A at $41^{\circ} 00.016^{\prime} \mathrm{N}, 127^{\circ} 29.685^{\prime} \mathrm{W}$. A VIT survey was conducted. The seafloor was tagged at $3234.0 \mathrm{mbrf}$, and Hole $1038 \mathrm{H}$ was spudded at $1030 \mathrm{hr}$ on 8 October. XCB Cores $169-1038 \mathrm{H}-1 \mathrm{X}$ through $20 \mathrm{X}$ were taken from 0 to $192.8 \mathrm{mbsf}$ with $16 \%$ recovery. The bit cleared the seafloor at $1400 \mathrm{hr}$ on 9 October.

\section{Hole 1038I}

The ship was moved $250 \mathrm{~m}$ south and $130 \mathrm{~m}$ east from Hole 1038A onto Central Hill. An XCB core barrel was run. The seafloor was tagged with the bit at 3227.0 mbrf. Hole 1038I was spudded at $1600 \mathrm{hr}$ on 9 October. XCB Cores 169-1038I-1X and 2X were taken from 0 to 17.3 mbsf with $55.7 \%$ recovery. APC Cores $169-1038 \mathrm{I}-3 \mathrm{H}$ through $7 \mathrm{H}$ were taken from 17.3 to 64.8 mbsf with $102.0 \%$ recovery. An Adara temperature measurement was taken on Core 169-1038I$3 \mathrm{H}$, and the Davis-Villinger Temperature Probe was run after Core 169-1038I-6H at 55.3 mbsf. The last three APC cores were partial strokes with 50,000 to $60,000 \mathrm{lb}$ overpull so APC coring was terminated. XCB Cores 169-1038I-8X through 43X were taken from 64.8 to $404.0 \mathrm{mbsf}$ ( $3631.0 \mathrm{mbrf}$ ) with $40.0 \%$ recovery. Coring was terminated when time for operations on Leg 169 expired.

\section{Drill Pipe Loss}

Coring was finished at Hole 1038I, and 123 stands (1200 m) of 5-in drill pipe had been pulled to prepare for the transit to Los Angeles. The seafloor had been cleared, and the ship had been moved slowly in DP mode $\sim 0.4 \mathrm{nmi}$ southeast of Central Hill (in preparation for changing out the coring wire line) to $40^{\circ} 59.60^{\prime} \mathrm{N}, 127^{\circ} 28.98^{\prime} \mathrm{W}$. While pulling pipe at $\sim 1700 \mathrm{hr}$, the workers attempted to put both bails under the pickup elevator ears, but only one bail engaged. When the elevators were picked up, the engaged bail tilted the elevator, slipped off the ear, and broke off the end of the elevator-ear latch. The elevators flipped up on one side, and the 5 -in drill pipe bent and broke $0.7 \mathrm{~m}$ below the top of the tool joint box. No one was injured. The incident can be attributed to combined operator and crew error, with end-of-leg fatigue as an extenuating factor. Lost on the seafloor were 81 stands $(2298 \mathrm{~m})$ of 5 -in drill pipe and $127 \mathrm{~m}$ of BHA.

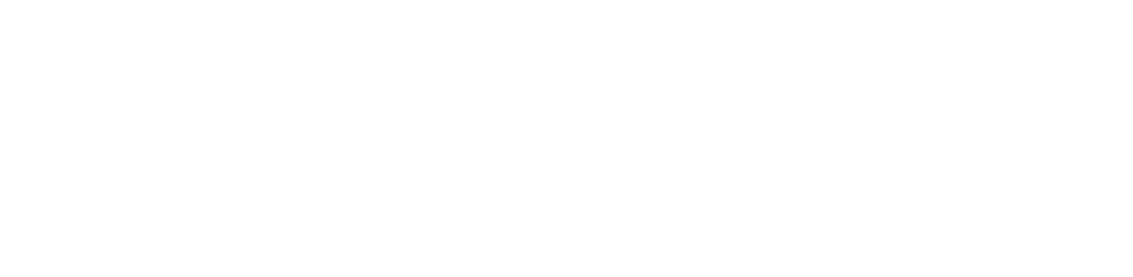

